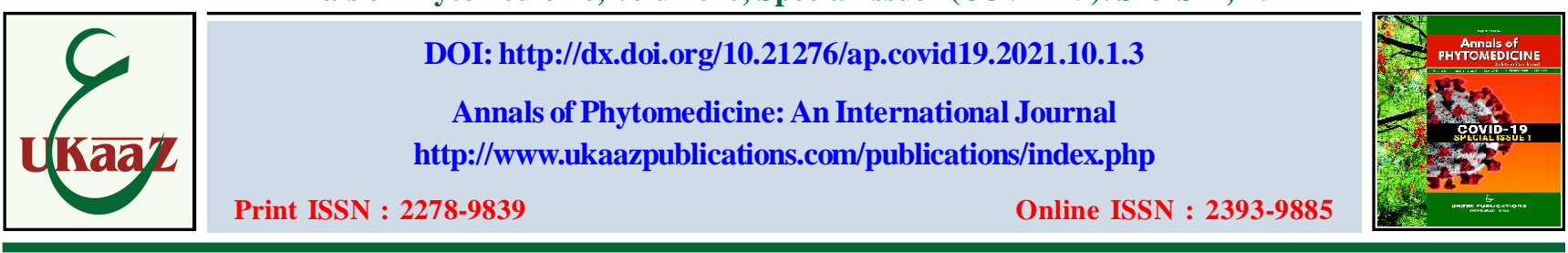

\title{
Correlation of COVID-19 with Parkinson's disease and life expectancy indicates female population predominance in future
}

\author{
Abdulrahman M. Alshahrani*, Yusuf Jamal*, Feras M. Almarshad, Aslam Pathan** and Jamal M. Arif** \\ Department of Internal Medicine, College of Medicine, Shaqra, Shaqra University, Shaqra-11961, Saudi Arabia \\ *Faculty of Medicine, Ternopil National Medical University, Voli Square, 1, Ternopil, Ternopil Oblast-46002, Ukraine \\ **Department of Basic Medical Sciences, Shaqra, College of Medicine, Shaqra University, Shaqra-11961, Saudi Arabia
}

\section{Article Info}

Article history

Received 13 May 2021

Revised 29 June 2021

Accepted 30 June 2021

Published Online 30 June 2021

\section{Keywords}

COVID-19

Parkinson's disease

Life expectancy

Mortality rate

CFR

\begin{abstract}
Neurological diseases are prevalent in the populations from the developed nations including Europe and North America, while South America also shows a high prevalence of Parkinson's disease (PD). Although, PD is among the most prevalent neurodegenerative conditions, its cause remains largely unknown. Changing age structure and marked demographic shifts, with progressively larger percentage of their populations entering old age, has been seen in many countries. Females have been found to have a higher life expectancy and longevity than males at any age. We compiled the freely available data on COVID-19, and statistics on life expectancy, and ageing population from the United Nations. The XY-scatter plots with regression analysis were used to assess the correlation between case fatality rate (CFR)/deaths and life expectancy of various countries. We infer that the SARS-CoV-2 mediated infections mostly affected the elderly people of age $60+$ years, who accounted for approximately $50 \%(20-88.45 \%)$ of the total deaths by COVID-19. However, females were found to be 1.66 times less prone to COVID-19-induced deaths compared to the males. The X Y-scatter plot showed no correlation between life expectancy and CFR or deaths due to COVID-19. Similar patterns of CFR/deaths by COVID-19 and PD prevalence were also observed in Europe and America. All the factual data including increased susceptibility of males to COVID-19 and PD, along with relatively less life expectancy than females, indicate that the world may virtually be heading towards a predominantly female older population. However, caution may be exercised in interpreting the results of this preliminary study that may be affected by incorrect or biased reporting on COVID-19 data, regional variations in the infectivity by new mutant strains of SARC-COV-2, and the prevalence and epidemiology of PD and COVID-19 might also affect the associated risk factors for PD in certain population.
\end{abstract}

\section{Introduction}

Ever since the emergence and outbreak of the coronavirus (2019$\mathrm{nCoV}$ ) in Wuhan province of China, in December 2019, the coronavirus disease (COVID-19) has been wreaking havoc across the globe (Huang et al., 2020; Zhu et al., 2020). The COVID-19 pandemic has affected almost all the countries worldwide, with similar intensity, presenting an unprecedented challenge to public health without allowing time for its management. Furthermore, in several countries like India, it has spread rapidly despite stringent measures taken by the Government for its containment. In the beginning, several countries such as Italy, Spain, and Iran were seen to be affected by the disease but later US, Brazil, India, and Mexico, were seen battling with several fold higher number of COVID-19 positive cases and deaths (www.worldometers.info). By November 13, 2020, the total number of deaths caused by COVID-19 worldwide, crossed the 1.3 million mark which has stretched to 3.5 million deaths in May 2021 (Worldometer, May 24, 2021). The statistical data on COVID-19 prevalence, case fatality rates (CFR) and deaths seems to be frailed with several factors including variations in number of tests per million

Corresponding author: Dr. Abdulrahman M. Alshahrani Associate Professor, Department of Internal Medicine (Neurology), College of Medicine, Shaqra, Shaqra University, Shaqra-11961, Saudi Arabia

E-mail: alshahrani.md@su.edu.sa

Copyright () 2021 Ukaaz Publications. All rights reserved.

Email: ukaaz@yahoo.com; Website: www.ukaazpublications.com population, health infrastructure, social unawareness, and political vendetta, among many others. Nevertheless, it has highly affected the older population, generally living with naturally decreased immunity alongside several old age-related diseases (Mallapaty et al., 2020).

Most countries are experiencing an increase in the proportion and size of the elderly population (aged 65+ years) (United Nations World Population Prospects Report, 2019). The world's population of old age persons (65 years and above) is expected to double from the current 703 million to 1.5 billion, in 2050, which will account for $16 \%$ of the world's population. Asia, Europe, and North America were home for the older people in 2019, with East and South-East Asia having 261 million people aged $65+$ years, followed by Europe and North America (200 million each) (United Nations World Population ageing Report, 2019). However, the regions with largest projected increase in the number of older people, by 2050, include North Africa and West Asia (+230\%), sub-Saharan Africa (+220\%), Oceania $(+190 \%)$, Central and South Asia $(+180 \%)$, Latin America and the Caribbean $(+160 \%)$, and East and South-East Asia $(+120 \%)$ (United Nations World Population Prospects Report, 2019).

Ageing is known to play a key role in escalating neurodegenerative disorders like Parkinson's disease (PD) and Alzheimer's disease (AD). In the new millennium, neurological disorders are a major cause of disability. Unfortunately, currently there are no treatments to curb the growth and development of these neurodegenerative diseases. 
Recent statistics show that currently more than 50 million people are living with $\mathrm{AD}$ and more than 10 million people are suffering from PD worldwide (Alzheimer statistics, 2020; Parkinson statistics, 2020). Generally, the developed countries display a higher prevalence of these neurological diseases, but the South American countries have exceptionally been reported to show higher rates of PD prevalence (Pringsheim et al., 2014). Marras et al. (2018) reported the overall prevalence of PD to be 572 per 100,000 , among the people aged $\geq 45$ years in the United States. Furthermore, it has been reported that around 680,000 persons aged $\geq 45$ years in the US, were suffering with PD in 2010, which is expected to rise to approximately 930,000 and 1,238,000 in 2020 and 2030, respectively (Marras et al., 2018; Parkinson statistics, 2020). The incidence of $\mathrm{PD}$ is some what directly proportional to the increasing age, and it is predicted that about $4 \%$ of the people over the age of 50 years are susceptible to $\mathrm{PD}$, which affects men approximately 1.5 times more than women (Parkinson statistics, 2020).

Additionally, another neurological disease, $\mathrm{AD}$, is prevalent in Western Europe and North America while Sub-Saharan Africa shows the least prevalence of $\mathrm{AD}$ (Alzheimer statistics, 2020). Currently, more than 5 million Americans are living with $\mathrm{AD}$, which is projected to increase to 16 million, by 2050 (Alzheimer statistics, 2020). Further, the proportion of people with $\mathrm{AD}$ in the US, in 2020, is $38 \%$ for the people with age $85+$ years which is projected to increase to $51 \%$ of all people 65+ with $\mathrm{AD}$ (13.8 million) (Alzheimer statistics, 2020). However, interestingly $68 \%$ of the projected increase in the global burden of dementia and $\mathrm{AD}$ has been predicted in low and middleincome countries.

Regardless of these diseases and their underlying causes, a common major factor for them is the growing age. This means that adjustments within the brain, as it gets old, put it at a higher risk for the development of neurodegenerative disease. Our hypothesis is that the higher life expectancy in females with comparatively less severe effects and/or deaths due to COVID-19 and PD may result in their increased population in future. Our observations support this hypothesis as the results show approximately 1.5 times higher mortality in males due to COVID-19 and PD compared to the females which implies an increased female population in future (United Nations World Population Ageing Report, 2019).

\section{Materials and Methods}

Data used in this study related to coronavirus, life expectancy, Parkinson, and Alzheimer's statistics were freely available at various websites (Alzheimer statistics, 2020; Center for Evidence-based Medicine, 2020; Our World in Data; 2020; Parkinson statistics, 2020; Worldometer, 2020 and 2021). We also obtained the freely available statistics on life expectancy, and ageing population from the United Nations (United Nations World Population Prospects Report, 2019; United Nations World Population Ageing Report, 2019). Some data was also extracted from Pringsheim et al. (2014) for comparison purpose only. The $\mathrm{XY}$-scatter plots with regression analysis are shown for the correlation of CFR/deaths and life expectancy in various countries. We also plotted the XY-scatter plot between the life expectancy at birth and at age 65 .

\section{Results and Discussion}

\subsection{Ageing and life expectancy}

The age structure of people worldwide is constantly changing, and many developing nations are seeing more elderly people, primarily due to the increased life expectancy. Many factors such as gender, genetics, lifestyle, quality, and healthcare, contribute significantly to the increased life expectancy (Life expectancy by country, 2020).

The data, extracted from the United Nations report on ageing, 2019 and compiled in Table 1, shows that worldwide $35.2 \%$ (2.73 billion) of the world population ( 7.8 billion) today is at the age of 60 years and above. Most of this aged population is living in Europe, North America, Oceania, Asia and Latin America, and the Caribbean. Approximately 2-to3-fold increase in the growth of the $60+$ population was observed in these regions in the last 69 years since 1950 , except Africa, which did not record any increase in the percentage of the population in the $60+$ age group. This may be attributed to the relatively poor economic and health infrastructure. Further, among the older population, the people aged 60-64 years contributed the highest percentage of population in all the regions, including Africa (Table 1).

Table 1: Percentage of total population in 60+ age group (both sexes)

\begin{tabular}{|l|c|c|c|c|c|c|c|c|}
\hline Regions & Year & $\mathbf{6 0 - 6 4}$ & $\mathbf{6 5 - 6 9}$ & $\mathbf{7 0 - 7 4}$ & $\mathbf{7 5 - 7 9}$ & $\mathbf{8 0 - 8 4}$ & $\mathbf{8 5 - 8 9}$ & $\mathbf{9 0 +}$ \\
\hline World & 1950 & 8.0 & 5.1 & 2.9 & 1.4 & 0.6 & 0.2 & 0.0 \\
& 2020 & 13.5 & 9.3 & 5.9 & 3.5 & 1.9 & 0.8 & 0.3 \\
\hline Africa & 1950 & 5.3 & 3.2 & 1.8 & 0.8 & 0.3 & 0.1 & 0.0 \\
& 2020 & 5.5 & 3.5 & 2.0 & 1.0 & 0.4 & 0.1 & 0.0 \\
\hline Asia & 1950 & 6.6 & 4.0 & 2.2 & 1.0 & 0.4 & 0.1 & 0.0 \\
& 2020 & 13.1 & 8.9 & 5.3 & 3.0 & 1.5 & 0.6 & 0.2 \\
\hline Europe & 1950 & 11.8 & 8.0 & 4.8 & 2.5 & 1.0 & 0.3 & 0.1 \\
& 2020 & 25.7 & 19.1 & 13.4 & 8.7 & 5.3 & 2.5 & 0.9 \\
\hline Latin America and the & 1950 & 5.6 & 3.5 & 2.0 & 1.0 & 0.5 & 0.2 & 0.1 \\
Caribbean & 2020 & 13.0 & 9.0 & 5.8 & 3.5 & 1.9 & 0.9 & 0.3 \\
\hline North America & 1950 & 12.3 & 8.2 & 4.7 & 2.5 & 1.1 & 0.5 & 0.1 \\
& 2020 & 23.1 & 16.8 & 11.4 & 7.0 & 4.0 & 2.0 & 0.8 \\
\hline Oceania & 1950 & 11.1 & 7.3 & 4.3 & 2.3 & 1.0 & 0.4 & 0.1 \\
& 2020 & 17.5 & 12.8 & 8.8 & 5.4 & 3.0 & 1.5 & 0.6 \\
\hline
\end{tabular}

Source: United Nations, Department of Economic and Social Affairs, Population Division (2019). [United Nations World Population Ageing Report (2019); United Nations World Population Prospects Report (2019)] 
Additionally, the growth and sustenance of improved economic social and health fabrics may be a driving force in the continuous increase in life expectancy at birth, which has increased by 8 years to 72.3 years in 2019 as compared to 1990 (Table 2). Furthermore, it is projected to rise to 77.1 years in 2050 (United Nations World Population Prospects Report, 2019).

Table 2: Life expectancy at birth and at age 65 (both sexes)

\begin{tabular}{|l|c|c|}
\hline \multirow{2}{*}{ Regions } & \multicolumn{2}{|c|}{ Life expectancy (Years) } \\
\cline { 2 - 3 } & Birth & $\mathbf{6 5}$ \\
\hline World & 72.30 & 17.00 \\
\hline Australia and New Zeeland & 83.00 & 21.20 \\
\hline Europe and North America & 78.50 & 19.10 \\
\hline Eastern and South East Asia & 76.30 & 17.20 \\
\hline Latin America and the Caribbean & 75.20 & 18.20 \\
\hline North Africa and West Asia & 73.50 & 16.00 \\
\hline Central and Southern Asia & 69.50 & 14.70 \\
\hline $\begin{array}{l}\text { Oceania excluding Australia and } \\
\text { New Zeeland }\end{array}$ & 66.30 & 12.60 \\
\hline Sub-Saharan Africa & 60.50 & 12.80 \\
\hline
\end{tabular}

Source: United Nations, Department of Economic and Social Affairs, Population Division (2019). [United Nations World Population Ageing Report (2019)].

With large regional variations that exist globally, by 2050 the life expectancy at age 65 is expected to increase by 12-21 years with the highest increase in Australia and New Zealand. In addition, by 2050, globally the number of people aged 65 years or above is also projected to surpass the number of adolescents and youth (15-24 years) (United Nations World Population Ageing Report, 2019).

Table 3: Distribution of population aged 65+ years in 2019 2050

\begin{tabular}{|c|c|c|c|}
\hline \multirow[b]{2}{*}{ Regions } & \multicolumn{2}{|c|}{ Per cent share } & \multirow{2}{*}{$\begin{array}{l}\text { Percen } \\
\text { change }\end{array}$} \\
\hline & 2019 & 2050 & \\
\hline Eastern and South East Asia & 37.0 & 37.0 & 0.0 \\
\hline Europe and North America & 28.5 & 19.1 & $9.4(-)$ \\
\hline Central and Southern Asia & 16.9 & 21.0 & $4.1(+)$ \\
\hline Latin America and the Caribbean & 8.0 & 9.0 & $1.0(+)$ \\
\hline Sub-Saharan Africa & 5.0 & 7.0 & $2.0(+)$ \\
\hline North Africa and West Asia & 4.0 & 6.0 & $2.0(+)$ \\
\hline
\end{tabular}

Source: United Nations, Department of Economic and Social Affairs, Population Division (2019). [United Nations World Population Ageing Report (2019)].

Interestingly, all the regions are expected to observe the increase in percentage share of the population aged 65 years and above in 2050, as compared to 2019 (Table 3). The biggest increase could be seen in Central and Southern Asia $(4.1 \%)$ while East and SouthEast Asia may remain unchanged (Table 3). To the contrary, Europe and North America have been projected to reduce their per cent share of people aged 65 and above by a whopping $9.4 \%$ to $19.1 \%$ in 2050 (Table 3) as suggested by the UN world population report (United Nations World Population Prospects Report, 2019). These are the only regions predicted to shrink their elderly population, and this unfortunately coincides with the number of deaths by COVID-19 reported in these regions (Worldometer, 2021). However, Australia and New Zealand, with the least number of deaths reported due to COVID-19, are predicted to show the highest increase in life expectancy at 65 years (Table 6) (Worldometer, 2020; United Nations World Population Aging Report, 2019). Further, a positive and significant correlation between life expectancy at birth and at the age 65 , for both genders, was observed in the XY-scatter plot (Figure 1) which subsequently indicates that the life expectancy at the age of 65 years could be considered for comparative studies with COVID-19 and PD prevalence or mortality in various regions.

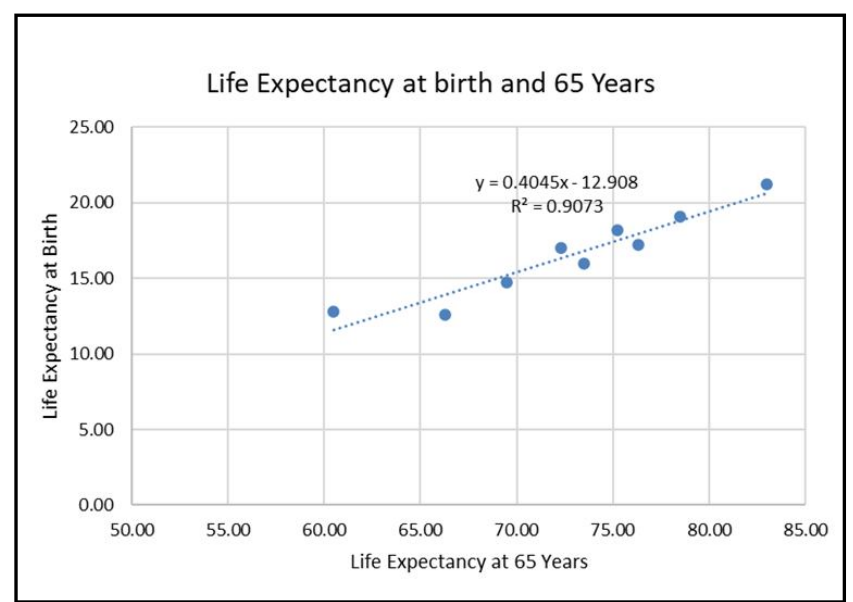

Figure 1: Relationship between life expectancy at birth and 65 years (Data was used from Table 2).

With regard to the gender-based life expectancy, females are known to outlive the males, all over the world. Globally, the females tend to show a better life longevity than males, leading to a predominantly female older population. Studies indicate that longevity is generally based on genetics and lifestyle choices (Cohut et al., 2018; Govindaraju et al., 2015; Passarino et al., 2016; Pignolo et al., 2019). The UN-WPA Report (United Nations World Population Ageing Report, 2019) suggests that, in 2050, females will comprise of $54 \%$ of the global population aged 65 years or above. Globally, it has been reported that the continuous improvement in female life expectancy at birth exceeds that of males by 4.8 years in 2015-20, with the largest average longevity (6.5 years) recorded in Latin America and the Caribbean, followed by Europe and North America (6.1 years), East and South-East Asia (5.3 years), subSaharan Africa (3.5 years), Oceania (3.0 years and Central and South Asia (2.7 years) (United Nations World Population Ageing Report, 2019). Similarly, according to the statistics in 2015-20, the females at age 65 are also expected to live another 18 years while the males will live only 16 years (United Nations World Population Ageing Report, 2019). Furthermore, the proportion of women in the total population aged 80 years or over is expected to be $59 \%$ in 2050 (United Nations World Population Ageing Report, 2019). 
Table 4: Top ten countries with highest case fatality rate (CFR) in COVID-19 patients

\begin{tabular}{|l|l|l|l|}
\hline Country & $\begin{array}{l}\text { Case fatality } \\
\left(\begin{array}{c}\text { (on } \\
\text { April 09* }\end{array}\right.\end{array}$ & Country & $\begin{array}{l}\text { Case fatality } \\
\left(\begin{array}{c}\text { \%) } \\
\text { May 26** }\end{array}\right.\end{array}$ \\
\hline Algeria & 13.04 & France & 18.94 \\
\hline Italy & 12.67 & Belgium & 16.18 \\
\hline UK & 11.69 & Italy & 14.44 \\
\hline Netherlands & 10.94 & UK & 14.13 \\
\hline Belgium & 10.10 & Hungary & 13.69 \\
\hline Spain & 9.98 & Netherlands & 12.59 \\
\hline France & 9.62 & Mexico & 11.70 \\
\hline Indonesia & 8.50 & Sweden & 10.27 \\
\hline Sweden & 8.16 & Spain & 9.40 \\
\hline Morocco & 7.29 & Ecuador & 8.40 \\
\hline
\end{tabular}

*The data was accessed on April 13, 2020;

**The data was accessed on September 07, 2020

(www.cebm.net/covid/global-covid-19-case-fatality-rates/)

Table 5: COVID-19 case fatality rates by age in various countries

\begin{tabular}{|c|c|c|c|c|}
\hline $\begin{array}{c}\text { Age group } \\
\text { (Years) }\end{array}$ & $\begin{array}{c}\text { South Korea } \\
(\text { March 24) }\end{array}$ & $\begin{array}{c}\text { Spain } \\
(\text { March 24) }\end{array}$ & $\begin{array}{c}\text { China } \\
(\text { Feb 17) }\end{array}$ & $\begin{array}{c}\text { Italy } \\
\text { (March 17) }\end{array}$ \\
\hline $30-39$ & 0.11 & 0.14 & 0.2 & 0.3 \\
\hline $40-49$ & 0.08 & 0.3 & 0.4 & 0.4 \\
\hline $50-59$ & 0.5 & 0.4 & 1.3 & 1 \\
\hline $60-69$ & 1.8 & 1.9 & 3.6 & 3.5 \\
\hline $70-79$ & 6.3 & 4.8 & 8 & 12.8 \\
\hline $80+$ & 13 & 15.6 & 14.8 & 20.2 \\
\hline
\end{tabular}

www.ourworldindata.org/coronavirus accessed on April 14, 2020.

\subsection{Correlation between life expectancy and COVID-19-caused case fatality rates and deaths}

In the past two decades, three major coronaviruses caused epidemics of respiratory distress syndromes. The severe acute respiratory syndrome coronavirus (SARS-CoV) in 2003 was followed by the Middle East respiratory syndrome coronavirus (MERS-CoV) in 2012 and the respiratory coronavirus, the 2019 novel coronavirus (2019 $\mathrm{nCoV}$ ) or coronavirus disease (COVID 19) (Sarma et al., 2020). The 2019-nCoV has spread to 216 countries with fatalities totaling around 1,305,908 and 53,494,241 infections (Worldometer, Nov 13, 2020). The mortality rate varies from $\sim 1.5 \%(2019 \mathrm{nCoV})$, to $10 \%$ (SARS), and up to $35 \%$ in case of MERS-CoV (Sarma et al., 2020; Worldometer, 2020). However, the mortality rates increased with the increase in age and approximately $50 \%$ mortality was reported among the old age group of 65-85 years, except for certain countries like Italy, which has shown around $88 \%$ mortality in $60-90+$ age group (Center for Evidence-based Medicine, 2020).

As depicted by the data compiled in Table 4, the top 10 countries with the highest CFR include most European countries, throughout this pandemic. However, the highest number of deaths have been seen in America $(595,000)$ followed, by Europe $(229,954)$ and Asia
$(210,192)$; while Africa $(37,689)$ and Oceania 941 have recorded quite lower number of deaths due to COVID-19 (Worldometer, Nov 13, 2020). France has taken the top spot on May 26, 2020, with the highest CFR; however, Italy and Spain in Europe were in the competitive race of number of positive cases and deaths in MarchApril. Italy was one of the most affected European countries, which possibly has several reasons for higher CFR, such as being home to the second oldest population in the world, highest antibiotic resistance deaths in Europe and high smokers' population (Center for Evidencebased Medicine, 2020).

Generally, the reporting of deaths by various countries have been poised with many confounding factors but the percentage of the COVID-19 deaths recorded among the older population (60+ years) is almost consistent in every country (Oke et al., 2020). Further, in Table 5, the combined data for the 60-85+ age group coincides with higher CFR. The data accessed on April 14, 2020 suggests the high CFR of 21.1 in South Korea, 22.3 in Spain, 26.4 in China and 36.5 in Italy for the age group of 60-85+ years (Our World in Data, 2020). In another report, in March, again Italy showed quite high combined CFR of $88.45 \%$ in the males of the age group 60-90+ years; while females had a 1.66 times lower CFR of $53.23 \%$ (Center for Evidencebased Medicine, 2020). With a conservative view on the average CFR of $50 \%$ in the $60+$ age population, over 500,000 deaths out of 1 million deaths, as on September 30, 2020, may be attributed to the $60+$ years population. However, a decline in the pattern of CFR is being observed throughout the world due to the occurrence of new cases in predominantly younger population with a better outcome (Oke et al., 2020).

Coincidently, with higher longevity, the females have also shown better resistance to COVID-19 than males, which has translated into lesser number of deaths in females (Gemmati et al., 2020; Worldometer, Nov 13, 2020). While men and women have the same prevalence, men with COVID-19 are 1.5-3.5 times more at risk for worse outcomes and death (Gemmati et al., 2020; Global Health 5050, 2020; Jin et al., 2020; Na et al., 2020; Sharma et al., 2020; Worldometer, 2020).

The 2019-nCoV expresses four types of proteins (spike, membrane, envelope and nucleocapsid proteins) and several treatment options are based on targeting these proteins (Prajapat et al., 2020). Researchers have isolated the virus particle, sequenced it, and analyzed the genetic template for spike proteins on the surface of the virus, which help it to penetrate the outer walls of human and animal cells (Letko et al., 2020). More specifically, the receptorbinding domain (RBD) which effectively targets the ACE2 receptors is involved in regulating blood pressure through renin-angiotensin system, and the cleavage site to enter to the host cells (Letko et al., 2020; Andersen et al., 2020). Gemmati et al., (2020) predicted that the double X-chromosomes in females might be protective against the SARS-CoV-2 infection, owing to the presence of ACE2 gene on the $\mathrm{X}$-chromosome, making females potentially heterozygous compared to certain hemizygous men.

Further, in Table 6, we have compiled the data from various regions, countries, life expectancy and the total cases, deaths and CFR, using two sets of the available data on April 09 and September 07, 2020, to observe the correlation of life expectancy and CFR or deaths. When the data was put into regression analysis in XY-scatter plots, no significant correlation between life expectancy and CFR was observed (Figures 2 and 3). 
Table 6: Life expectancy and COVID-19 statistics in various countries in April and September, 2020

\begin{tabular}{|c|c|c|c|c|c|c|c|c|}
\hline \multirow[t]{2}{*}{ Region } & \multirow[t]{2}{*}{ Countries } & \multirow{2}{*}{$\begin{array}{c}\text { Life } \\
\text { expectancy } \\
(\text { Years })^{*}\end{array}$} & \multicolumn{2}{|c|}{ Total cases* } & \multicolumn{2}{|c|}{ Total deaths* } & \multicolumn{2}{|c|}{ CFR** } \\
\hline & & & April 09 & Sept. 07 & April 09 & Sept. 07 & April 09 & Sept. 07 \\
\hline \multirow[t]{2}{*}{ Oceania } & Australia & 83.94 & 5687 & 26322 & 51 & 762 & 0.84 & 2.89 \\
\hline & New Zeeland & 82.80 & 872 & 1776 & 1 & 24 & 0.08 & 1.35 \\
\hline \multirow[t]{10}{*}{ Europe } & Spain & 83.99 & 124736 & 517133 & 14792 & 29418 & 9.98 & 6.00 \\
\hline & Italy & 84.01 & 124632 & 277634 & 17669 & 35541 & 12.67 & 12.80 \\
\hline & Germany & 81.88 & 91714 & 251724 & 2349 & 9401 & 2.07 & 3.73 \\
\hline & France & 83.13 & 68605 & 324777 & 10669 & 30724 & 9.62 & 9.25 \\
\hline & $\mathrm{UK}$ & 81.77 & 41903 & 347152 & 7097 & 41551 & 9.62 & 11.97 \\
\hline & Switzerland & 84.25 & 20489 & 44401 & 705 & 2013 & 3.09 & 4.53 \\
\hline & Belgium & 82.17 & 18431 & 88367 & 2523 & 9907 & 10.10 & 11.21 \\
\hline & Netherlands & 82.78 & 16627 & 74787 & 2248 & 6243 & 10.94 & 8.35 \\
\hline & Austria & 82.05 & 11766 & 29271 & 295 & 736 & 2.27 & 2.51 \\
\hline & Portugal & 82.65 & 10524 & 60258 & 380 & 1840 & 2.89 & 3.05 \\
\hline \multirow[t]{11}{*}{ Asia } & China & 77.47 & 82575 & 85134 & 3335 & 4634 & 4.07 & 5.25 \\
\hline & Iran & 77.33 & 55743 & 386658 & 3993 & 22293 & 6.18 & 5.77 \\
\hline & Turkey & 78.45 & 23934 & 279806 & 812 & 6673 & 2.12 & 2.38 \\
\hline & South Korea & 83.50 & 10237 & 21296 & 204 & 336 & 1.96 & 1.58 \\
\hline & Israel & 83.49 & 8018 & 131641 & 73 & 1019 & 0.78 & 0.77 \\
\hline & Malaysia & 76.65 & 3483 & 9397 & 67 & 128 & 1.58 & 1.36 \\
\hline & India & 70.42 & 3374 & 4208646 & 178 & 71711 & 3.01 & 1.70 \\
\hline & Japan & 85.03 & 3271 & 72131 & 94 & 1370 & 2.01 & 1.90 \\
\hline & Phillipines & 71.68 & 3094 & 237365 & 203 & 3875 & 4.98 & 1.63 \\
\hline & Pakistan & 67.79 & 2450 & 298903 & 63 & 6345 & 1.43 & 2.12 \\
\hline & Indonesia & 72.32 & 2092 & 194109 & 280 & 8025 & 8.50 & 4.13 \\
\hline \multirow[t]{10}{*}{ America } & USA & 79.11 & $3,12,237$ & 6460421 & 14797 & 193253 & 3.40 & 3.02 \\
\hline & Canada & 82.96 & 13882 & 131895 & 435 & 9145 & 2.24 & 6.87 \\
\hline & Brazil & 76.57 & 10278 & 4137606 & 822 & 126686 & 5.08 & 3.06 \\
\hline & Chile & 80.74 & 4161 & 422510 & 48 & 11592 & 0.87 & 2.74 \\
\hline & Ecuador & 77.71 & 3465 & 118045 & 242 & 6724 & 5.44 & 5.70 \\
\hline & Mexico & 75.41 & 1890 & 634023 & 174 & 67558 & 5.47 & 10.66 \\
\hline & Panama & 79.10 & 1801 & 97043 & 63 & 2086 & 2.49 & 2.15 \\
\hline & Peru & 77.44 & 1746 & 689977 & 121 & 29838 & 2.79 & 4.32 \\
\hline & Dominican Rep & 74.65 & 1578 & 99333 & 108 & 1845 & 5.12 & 1.86 \\
\hline & Argentina & & 1451 & & 65 & 9859 & 3.62 & 2.06 \\
\hline \multirow[t]{5}{*}{ Africa } & South Africa & 64.88 & 1585 & 638517 & 18 & 14889 & 0.96 & 2.33 \\
\hline & Algeria & 77.50 & 1300 & 46364 & 205 & 1556 & 13.04 & 3.36 \\
\hline & Egypt & 72.50 & 985 & 99863 & 103 & 5530 & 6.60 & 5.54 \\
\hline & Morocco & 77.43 & 919 & 72394 & 93 & 1361 & 7.29 & 1.88 \\
\hline & Cameroon & 60.32 & 555 & 19604 & 9 & 415 & N/A & 2.12 \\
\hline
\end{tabular}

* Data extracted from www.worldometers.info on April 14 and September 07, 2020.

**Data extracted from www.statista.com and www.ourworldindata.org on April 14 and September 07, 2020.N/A = not available. 
Table 7: Prevalence of Parkinson's disease with age, gender, and region

\begin{tabular}{|l|l|l|l|l|l|l|}
\hline Age (Years) & $\begin{array}{l}\text { Prevalence } \\
\text { of PD }\end{array}$ & Male & Female & $\begin{array}{l}\text { Europe, } \\
\text { North America, } \\
\text { Australia }\end{array}$ & Asia & $\begin{array}{l}\text { South } \\
\text { America }\end{array}$ \\
\hline $40-49$ & 41 & - & - & - & - & - \\
\hline $50-59$ & 107 & 134 & 41 & - & - & - \\
\hline $60-69$ & 428 & - & - & - & - & - \\
\hline $70-79$ & 1087 & - & - & 1602 & 646 & 2180 \\
\hline $80+$ & 1903 & 2010 & 1517 & 2953 & 1418 & 6095 \\
\hline Overall & 315 & - & - & - & - & - \\
\hline
\end{tabular}

Data is represented as $\mathrm{PD} / 100000$

Data was extracted from Pringsheim et al. (2014)

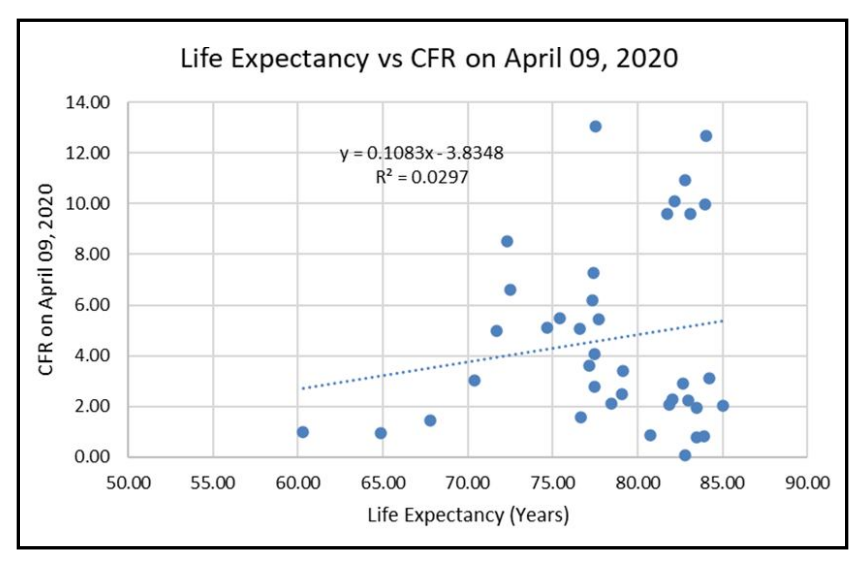

Figure 2: Correlation of life expectancy with the COVID-19 CFR reported on April 09, 2020 in various countries. Data was used from Table 6 .

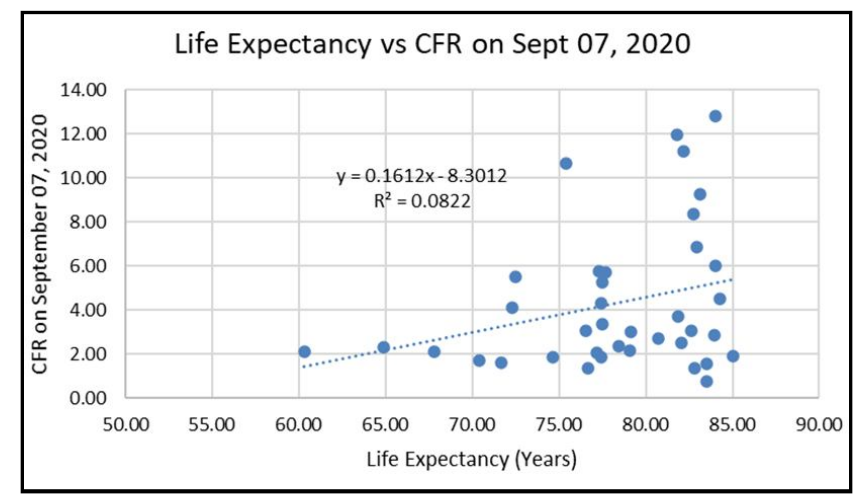

Figure 3: Correlation of life expectancy with the COVID-19 CFR reported on September 07, 2020 in various countries. Data was used from Table 6.

Furthermore, as shown in Figure 4, we have used the combined data of top 10 countries from each region with the highest positive cases and CFR/deaths. Oceania had reported the lowest number of deaths due to COVID-19 amounting to around 1000 cases, followed by Africa $(38,000)$, Europe $(230,000)$, Asia $(210,000)$ and America $(595,000)$ as on October 10, 2020 (Worldometer, Oct 10, 2020). In the XY-scatter plot with regression analysis, we did not observe any significant correlation between life expectancy and the total number of deaths (Figure 4). This is contrary to the report by Hallal et al.
(2020) which showed a moderate correlation between mortality and life expectancy. A possible explanation could not be ascertained but except that the data used by Hallal et al. (2020) was procured between March-April when the pandemic was in its infancy, with several confounding factors such as varying number of tests per million in different countries, which led to relatively lower number of positive cases and deaths in Asia. During the pandemic, almost every country has experienced an ever-changing pattern in the prevalence and mortality by COVID-19 and we believe we could avail relatively more stable data compared to that from March-April (Worldometer, Oct 10, 2020). This makes our observation relatively more reliable because of the two different sets of data collected in April and September to plot the life expectancy and CFR or total deaths (Figures 2-4). Nevertheless, the real statistics and underlying causes, confounding factors, availability of data on deaths by genders, and mechanism(s) might not be accurately known till the pandemic is over and the detailed analysis of data is performed to exactly know the correlation between gender-based CFR and life expectancy.

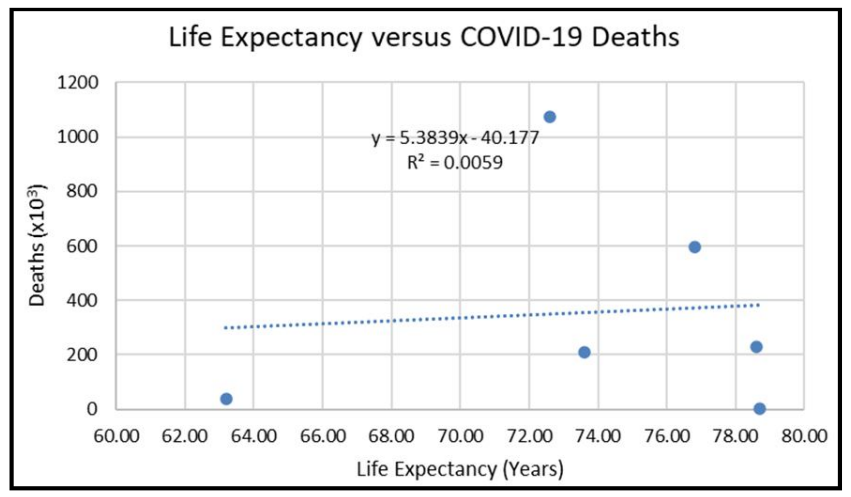

Figure 4: Correlation of life expectancy with the COVID-19 deaths in various regions.

\subsection{Correlation between COVID-19 and PD}

One of the most reliable causes of PD in various countries is old age and longevity (Pringsheim et al., 2014; Alzheimer statistics, 2020; Parkinson statistics, 2020). Genetic susceptibility and various environmental factors may play pivotal roles in the etiology of PD. In 2014, Pringsheim et al., published a report on the PD prevalence and distribution in various regions. We extracted some data from the published report to reveal that the population over 60 years of age, particularly males (1.5 times more than females), are more 
prone to PD (Table 7). Further, the regional variations in PD prevalence were quite interesting as the COVID-19-induced positive case prevalence and CFR/deaths also showed very similar patterns in Europe and Americas. However, the observations are preliminary owing to the unavailability of long-term neurological impact assessment of COVID-19.

There are several reviews and research articles that attempt to explain the role of COVID-19 on the central and peripheral nervous systems (DosSantos et al., 2020; Najjar et al., 2020; Niazkar et al., 2020; Payus et al., 2020; Sharifian-Dorche et al., 2020; YavarpourBali et al., 2020). PD is one of the neurological complications affecting the dopamine-producing neurons (Triarhou et al., 2013). Interestingly, several researchers have hypothesized an association between COVID-19 pathophysiology and alteration in dopamine synthesis pathway (Kuba et al., 2005; Yavarpour-Bali et al., 2020). They have demonstrated that dopa decarboxylase (DDC) is significantly co-expressed with ACE2 receptor which could dysregulate the serum dopamine levels in the COVID-19 patients, subsequently affecting the severity of PD (Nataf et al., 2020). Further, the virus may also cause sporadic PD in infected individuals.

Early reports suggested the direct involvement of the central nervous system in COVID-19 as a 74-year-old PD patient developed encephalopathy (Filatov et al., 2020). Further, a poor outcome due to the older age, disease length and advanced therapies, with $40 \%$ mortality due to COVID-19, was first reported in 10 PD patients in Italy and UK (Antonini et al., 2020; Prasad et al., 2020). However, Fasano et al. (2020) reported $19.7 \%$ mortality in COVID-19 patients with obesity, dementia, hypertension, and PD in a multicentered cohort of 117 PD patients with COVID-19. Further, the $88.45 \%$ deaths in the 60-90+ aged patients with COVID-19 seen in certain countries such as Italy, could be due to many confounding factors as discussed above, but in all possibility the overall prevalence and incidence of PD worldwide could see a significant increase in the coming decades. The reported post-COVID-19 complications may trigger various physiological, biochemical, and clinical manifestations, which could accelerate the early onset of PD in the younger population below 50 years of age; however, the actual data on PD prevalence could take decades to be visible. A controlled and welldesigned multicenter clinical study with a large sample size of patients with PD and COVID-19 in the $60+$ population, may provide better clinical correlation and prevalence of PD in future. The females are about 1.5 times less prone to PD and COVID-19 than the males along with their higher life expectancy and longevity, pointing towards a female predominant world by 2050 (United Nations World Population Aging Report, 2019).

Currently, with limited data on the effect of SARS-CoV-2 on the nervous system, the real impact of COVID-19 on the old age-relateddiseases like PD and AD is hard to predict (Achbani et al., 2020; Ferini-Strambi et al., 2021). The aggravation of specific motor and non-motor symptoms including persistent hyposmia in COVID-19 patients certainly warrants regular monitoring of those subjects after recovery (Gatto et al., 2020; Sulzer et al., 2020). However, to ascertain the long-term impact of COVID-19 on nervous systemrelated diseases, intensive research through multicentered cohort studies involving the PD and AD patients, clinical studies, postmortems and physiological studies, in vitro and in vivo, will be required to pinpoint neuroinvasive behaviors of SARS-CoV-2 (Marshall et al., 2020).
The interpretation of the results of this preliminary study are likely to be affected by the incorrect or biased reporting on COVID-19 data, regional variations in the infectivity rate of the new mutant strains of SARC-CoV-2, prevalence and/or epidemiology of PD and COVID-19 in different regions, and the associated risk factors for PD in certain population. A similar study may be planned well after the end of the pandemic to see the real impact of COVID-19 on PD prevalence and survival rates in both genders to draw a better correlation with the predicted predominantly female population in future.

\section{Conclusion}

The present study observed that life expectancy, in general, does not correlate with the CFR or deaths (for both genders combined) due to COVID-19; however, an exception to this are Australia and New Zealand having the highest life expectancies in the world but significantly lower COVID-19-caused deaths. Further, death rates in females due to COVID-19 are reported to be approximately 1.66 times lower than males. With higher life expectancy and longevity in females at the time of birth or at the age of 80 and over, compared to males as predicted by the UN population and ageing statistics reports, is well correlated by the fact that females showed 1.5 times less severe outcomes of PD prevalence compared to males. The severity of COVID-19 in males might trigger a variety of physiological, biochemical, and clinical changes possibly preponing the PD onset, which may be seen in the future prevalence and incidence of PD with changing variations in different regions. Nevertheless, all data collectively indicate a possible female predominant world in future; however, the actual outcome and impact of COVID-19 might be seen years after the pandemic is over.

\section{Acknowledgements}

The authors acknowledge the technical support from the Deanship of Postgraduate and Scientific Research, Shaqra University, KSA.

\section{Conflict of interest}

The authors declare that there are no conflicts of interest relevant to this article.

\section{References}

Achbani, A.; Sine, H.; Naciri, A.; Baba, M.A.; Kharbach, A. and Bouchriti, Y. (2020). Can the 2019 novel coronavirus cause Parkinson's disease? Mov. Disord., 35:1102-1103 https://doi.org/10.1002/mds.28118.

Alzheimer Statistics (2020). https://www.alzheimers.net/resources/ alzheimers-statistics (Accessed Nov 13, 2020).

Andersen, K.G.; Rambaut, A.; Lipkin, WI.; Holmes, E.C. and Garry, R.F. (2020). The proximal origin of SARS-CoV-2. Nature Med., 26:450-52. doi:10.1038/s41591-020-0820-9

Antonini, A.; Leta, V.; Teo, J. and Chaudhuri, K.R. (2020). Outcome of Parkinson's disease patients affected by COVID-19. Mov. Disord., 35:905-08. Doi: $10.1002 / \mathrm{mds} .28104$

Center for Evidence-based Medicine (2020). (https://www.cebm.net/covid19/global-covid-19-case-fatality-rates/ (Accessed Oct 12, 2020)

Cohut, M. (2018). What is the secret to women's longevity? https:// www.medicalnewstoday.com/articles/324033. (Accessed Oct 27, 2020) 
DosSantos, M.F.; Devalle, S.; Aran, V.; Capra, D.; Roque, N.R. and Coelho-Aguiar J.M. (2020). Neuromechanisms of SARS-CoV-2: A Review. Frontiers in Neuroanatomy, 14:37.doi:10.3389/fnana.2020.00037

Fasano, A.; Cereda, E.; Barichella, M.; Cassani, E.; Ferri, V.; Zecchinelli, A.L. and Pezzoli, G. (2020). COVID-19 in Parkinson's Disease Patients Living in Lombardy, Italy. Mov. Disord., 35:1089-93.doi:10.1002/ mds. 28176 .

Ferini-Strambi, L. and Salsone, M. (2021). COVID-19 and neurological disorders: Are neurodegenerative or neuroimmunological diseases more vulnerable? J. Neurol., 268:409-419 https://doi.org/10.1007/ s00415-020-10070-8.

Filatov, A.; Sharma, P.; Hindi, F. and Espinosa, P.S. (2020). Neurological complications of coronavirus disease (COVID-19): Encephalopathy. Cureus, 12:e7352.doi:10.7759/cureus.7352.

Gatto, E.M. and Boccazzi, J.F. (2020). COVID-19 and neurodegeneration: What can we learn from the past? Eur. J.Neurol., e45 https://doi.org/ 10.1111 /ene. 14311

Gemmati, D.; Bramanti, B.; Serino, M.L; Secchiero, P.; Zauli, G. and Tisato, V. (2020). COVID-19 and Individual Genetic Susceptibility/Receptivity: Role of ACE1/ACE2 Genes, Immunity, Inflammation and Coagulation. Might the Double X-Chromosome in Females Be Protective against SARS-CoV-2 Compared to the Single XChromosome in Males? Int. J. Mol. Sci., 21:34-74. doi:10.3390/ ijms21103474

Global Health 5050 (2020). The COVID-19: Sex-Disaggregated Data Tracker https://globalhealth5050.org/the-sex-gender-and-covid-19project/. (Accessed Nov 13, 2020).

Govindaraju, D.; Atzmon, G. and Barzilai, N.; (2015). Genetics, lifestyle and longevity: Lessons from centenarians. Appl. Transl. Genomics, 4:23-32. doi: 10.1016/j.atg.2015.01.001

Hallal, P.C. (2020). Worldwide differences in COVID-19-related mortality. Ciência and Saúde Coletiva, 25(Supl.1):2403-10.doi:10.1590/ 1413-81232020256.1.11112020.

Huang, C.; Wang, Y.; Li X.; Ren, L.; Zhao, J. and Hu, Y.; (2020). Clinical features of patients infected with 2019 novel coronavirus in Wuhan, China. The Lancet, 395(10223):497-06.doi:10.1016/S0140-6736(20) 30183-5.

Jin, J.M.; Bai, P.; He, W.; Wu, F.; Liu, X.F. and Han, D.M. (2020). Gender Differences in Patients With COVID-19: Focus on Severity and Mortality. Front. Public Health, 8:152.doi:10.3389fpubh. 2020. 00152 .

Kuba, K.; Imai, Y.; Rao, S.; Gao, H.; Guo, F. and Guan, B. (2005). A crucial role of angiotensin converting enzyme 2 (ACE2) in SARS coronavirusinduced lung injury. Nature Med., 11:875-79.doi:10.1038/nm1267

Letko, M.; Marzi, A. and Munster, V. (2020). Functional assessment of cell entry and receptor usage for SARS-CoV-2 and other lineage B betacoronaviruses. Nat. Microbiol., 5:562-69.doi:10.1038/ s4 1564-020-0688-y

Life expectancy by country 2020. https://worldpopulationreview.com/ countries/life-expectancy (Accessed Oct 10, 2020).

Mallapaty M. (2020). The coronavirus is most deadly if you are older and male - new data reveal the risks. Nature, 585:16-17.doi:10.1038/ d41586-020-02483-2.

Marras, C.; Beck, J.C.; Bower, J.H.; Roberts, E.; Ritz, B. and Ross, G.W. (2018) Prevalence of Parkinson's disease across North America. Npj Parkinson's Disease, 4:21.doi:10.1038/s41531-018-0058-0

Marshall, M. (2020). How COVID-19 can damage the brain. Nature 585(7825):342-343.doi: 10.1038/d41586-020-02599-5.PMID: 32934351 .
Najjar, S.; Najjar, A.; Chong, D.J.; Pramanik, B.K.; Kirsch, C. and Kuzniecky, R.I. (2020). Central nervous system complications associated with SARS-CoV-2 infection: Integrative concepts of pathophysiology and case reports. J. Neuroinflammation, 17:231.doi:10.1186s1 2974-020-01896-0

Nataf, S. (2020). An alteration of the dopamine synthetic pathway is possibly involved in the pathophysiology of COVID-19. Journal of Medical Virology, 92:1743-44. doi: 10.1002/jmv.25826.

Ng, J.; Bakrania, K.; Falkous, C. and Russell, R. (2020). COVID-19 Mortality Rates by Age and Gender: Why Is the Disease Killing More Men than Women? Available at https://www.rgare.com/knowledgecenter/media/research/covid-19-mortality-rates-by-age-andgender-why-is-the-disease-killing-more-men-than-women. [Accessed Oct 20, 2020].

Niazkar, H.R.; Zibaee, B.; Nasimi, A. and Bahri, N. (2020). The neurological manifestations of COVID-19: A review article. Neuro. Sci., 41(7): 1667-71.doi:10.1007/s10072-020-04486-3

Oke J, Howdon D, Heneghan C. (2020). Declining COVID-19 Case Fatality Rates across all ages: Analysis of German data. https://www.cebm. net/covid-19/declining-covid-19-case-fatality-rates-across-allages-analysis-of-german-data/ September 09, 2020

Our World in Data. Coronavirus (2020). https://ourworldindata.org/ coronavirus [Accessed April 14, 2020].

Parkinson Statistics (2020). https://www.parkinson.org/UnderstandingParkinsons/Statistics [Accessed Nov 13, 2020].

Passarino, G.; De Rango, F. and Montesanto, A. (2016). Human longevity: Genetics or Lifestyle? It takes two to tango. Immun. Ageing., 13:12. doi:10.1186/s12979-016-0066-z.

Payus, A.O.; Liew Sat Lin, C.; Mohd Noh, M.; Jeffree, M.S and Ali, R.A. (2020). SARS-CoV-2 infection of the nervous system: A review of the literature on neurological involvement in novel coronavirus disease-(COVID-19). Bosnian J Basic Medical Sciences, 20:283-292. doi: $10.17305 /$ bjbms.2020.4860

Pignolo, R.J. (2019). Exceptional Human Longevity. Mayo. Clin. Proc., 94:110-124. doi:10.1016/j.mayocp.2018.10.005

Prajapat, M.; Sarma, P.; Shekhar, N.; Avti, P.; Sinha, S. and Kaur, H. (2020). Drug targets for corona virus: A systematic review. Indian J. Pharmacol., 52:56-65.doi:10.4103/ijp.IJP_115_20

Prasad, S.; Holla, V.V.; Neeraja, K.; Surisetty, B.K.; Kamble, N. and Yadav, R. (2020). Parkinson's disease and COVID-19: Perceptions and implications in patients and caregivers. Mov. Disord., 35:912914. Doi: $10.1002 / \mathrm{mds} .28088$.

Pringsheim, T.; Jette, N.; Frolkis, A. and Steeves, T.D.L. (2014). The Prevalence of Parkinson's Disease: A Systematic Review and Meta-analysis. Mov. Disord., 29:1583-1590.doi:10.1002/mds.25945

Sarma, P.; Prajapat, M.; Avti, P.; Kaur, H.; Kumar, S and Medhi, B. (2020). Therapeutic options for the treatment of 2019 novel coronavirus: An evidence based approach. Indian J. Pharmacol., 52:1-5.doi: 10.4103/ijp.IJP_119_20

Sharifian-Dorche, M.; Huot, P.; Osherov, M.; Wen, D.; Saveriano, A. and Giacomini, P.S. (2020). Neurological complications of coronavirus infection: A comparative review and lessons learned during the COVID-19 pandemic. J. Neuro. Sci., 417:117085.doi:10.1016/ j.jns.2020. 117085 .

Sharma, G.; Volgman, A.S. and Michos, E.D. (2020). Sex Differences in Mortality From COVID-19 Pandemic. J. Am. Coll. Cardiol. Case Rep., 2(9): 1407-1410. 
Sulzer, D.; Antonini, A.; Leta, V.; Nordvig, A.; Smeyne, R.J. and Goldman, J.E. (2020). COVID-19 and possible links with Parkinson's disease and parkinsonism: From bench to bedside. npj Parkinsons Dis., 6:18 https://doi.org/10.1038/s41531-020-00123-0.

Triarhou, L.C. (2013). Dopamine and Parkinson's Disease. In: Madame Curie Bioscience Database (Internet). Austin (TX): Landes Bioscience, 2000-2013. Available from: https://www.ncbi.nlm.nih. gov/books/NBK6271/

United Nations World Population Ageing Report (2019). https://www.un.org/ en/development/desa/population/publications/pdf/ageing/World Population Ageing Highlights, pdf [Accessed Oct. 27, 2020].
United Nations World Population Prospects Report (2019). https:// population.un.org/wpp/Publications/Files/WPP2019_Highlights. pdf [Accessed Oct 27, 2020].

Worldometer. Coronavirus (2020). https://www.worldometers.info/ coronavirus [Accessed Oct 10, 2020; Nov 13, 2020 and May 24, $2021]$.

Yavarpour-Bali, H. and Ghasemi-Kasman, M. (2020). Update on neurological manifestations of COVID-19. Life Sci., 257:118063. doi:10.1016/ j.1fs.2020.118063

Zhu, N.; Zhang, D.; Wang, W; Li X, Y ang B, Song J. (2020). A Novel Coronavirus from Patients with Pneumonia in China 2019. N Engl. J. Med. 382:727-33. doi: 10.1056/NEJMoa2001017.

Abdulrahman M. Alshahrani, Yusuf Jamal, Feras M. Almarshad, Aslam Pathan and Jamal M. Arif (2021). Correlation of COVID-19 with Parkinson's disease and life expectancy indicates female population predominance in future. Ann. Phytomed., Volume10, Special Issue1 (COVID-19): S13-S21. http://dx.doi.org/10.21276/ap.covid19.2021.10.1.3 